\title{
Note
}

\section{The First Record for Altai Fescue, Festuca altaica (Poaceae), in Nova Scotia, from an Eastern Alpine Site on Cape Breton Island}

\author{
Stephen Darbyshire ${ }^{1}$, Sean Blaney ${ }^{2,4}$, and Sean Basquill ${ }^{3}$ \\ ${ }^{1}$ Agriculture and Agri-Food Canada, Ottawa Research and Development Centre, Building 49, 960 Carling Avenue, Ottawa, \\ Ontario K1A 0C6 Canada \\ ${ }^{2}$ Atlantic Canada Conservation Data Centre, P.O. Box 6416, Sackville, New Brunswick E4L 1G6 Canada \\ ${ }^{3}$ Nova Scotia Department of Natural Resources, Wildlife Division, 136 Exhibition Street, Kentville, Nova Scotia B4N 4E5 \\ Canada \\ ${ }^{4}$ Corresponding author: sblaney@mta.ca
}

Darbyshire, Stephen, Sean Blaney, and Sean Basquill. 2017. The first record for Altai Fescue, Festuca altaica (Poaceae), in Nova Scotia, from an eastern alpine site on Cape Breton Island. Canadian Field-Naturalist 131(2): 164-169. https://doi.org $/ 10.22621 /$ cfn.v131i2.1861

Altai Fescue, Festuca altaica Trinius, is an amphi-Beringian grass species also known from isolated, but widespread, locations in northeastern North America. The occurrence reported here, at the southern limit of eastern alpine habitat in Canada, represents the first for Nova Scotia.

Key Words: Altai Fescue; Festuca altaica; conservation; rare plants; floristics; alpine vegetation; Nova Scotia

The distribution of Festuca altaica Trinius ranges from the Altai Mountains of central Asia (Tsvelev 1983) eastward and northward across the Bering Sea to northwestern North America and, from there, southward in British Columbia and western Alberta in alpine tundra (Pavlick and Looman 1984; Alexeev 1985; Harms 1985; Darbyshire and Pavlick 2007; Saarela et al. 2017). It also occurs in scattered areas in boreal forest and alpine regions of eastern North America, including northern Michigan, Quebec, Labrador, and western Newfoundland (Darbyshire and Pavlick 2007; Figure $1)$.

Here we document its first known occurrence in Nova Scotia, where a small but well established population was discovered during a qualitative botanical survey north of Polletts Cove, Cape Breton Island (Figure 2), in 2013. Although only a single localized population was found near the edge and crest of the plateau, more sites may well be found in this poorly explored region of fragmented barrens. This site is approximately $150 \mathrm{~km}$ and $340 \mathrm{~km}$ from the species' nearest locations in western Newfoundland and southeastern Quebec, respectively, which are isolated by ocean water (Figure 1). The plant occurred in small, scattered patches (none larger than a few square metres) over an area of about $50 \times 10 \mathrm{~m}$, within a tundra-like grassland, treeless (except for a few scattered krumholtz White Spruce, Picea glauca (Moench) Voss) and containing scattered forbs and shrubs. This habitat is classified as eastern alpine vegetation, which is one of the habitats in eastern Canada most vulnerable to environmental and climatic changes (Jones and Wiley 2012; Capers et al. 2013).

The scattered meta-populations of $F$. altaica in eastern Canada have sometimes been referred to other taxa in the taxonomically controversial Rough Fescue complex (section Breviaristatae), including Plains Rough Fescue (F. hallii (Vasey) Piper; Alexeev 1985) and Mountain Rough Fescue (F. altaica subsp. scabrella (Torrey) Hultén (=F. campestris Rydberg); Harms 1985). As indicated by Pavlick and Looman (1984), populations in eastern North America appear to be most closely linked with $F$. altaica (in the narrow taxonomic sense) through morphological, phytogeographical, and ecological aspects (Darbyshire and Pavlick 2007).

Festuca altaica occupies a wide range of substrates and habitats throughout its range, including sandy plains, rocky slopes, cliffs, and talus in open boreal, subarctic, and subalpine forests, as well as low arctic and alpine tundra. It is often present in serpentine barrens in British Columbia, Quebec, and Newfoundland, but is also present on limestone and Precambrian bedrock (herbarium label data). The northern plateau of Cape Breton Island, where the population occurs at $412-427 \mathrm{~m}$ above sea level, is composed of Precambrian igneous and metamorphic rock (Roland 1982; Barr et al. 1992). Soil at the site consists of a 6 -cm layer of humus over a fine, loamy-textured mineral soil about $20 \mathrm{~cm}$ deep.

In 2013, close associates of $F$. altaica and community structure were analyzed in two $25-\mathrm{m}^{2}$ plots within the area where this species is the dominant component. Plot SB1066 was at the crest of the slope on the plateau and SB1216 was on the upper slope (Figure 2, Table 1). The fieldwork was the first botanical exploration of the Polletts Cove plateau, and it documented numerous other provincially rare species with northern affinities both on the plateau and in the adjacent Blair River Valley (Table 2). Taxonomy and nomenclature in the tables follow Brouillet et al. (2010+), Esslinger (2015), and Ireland 


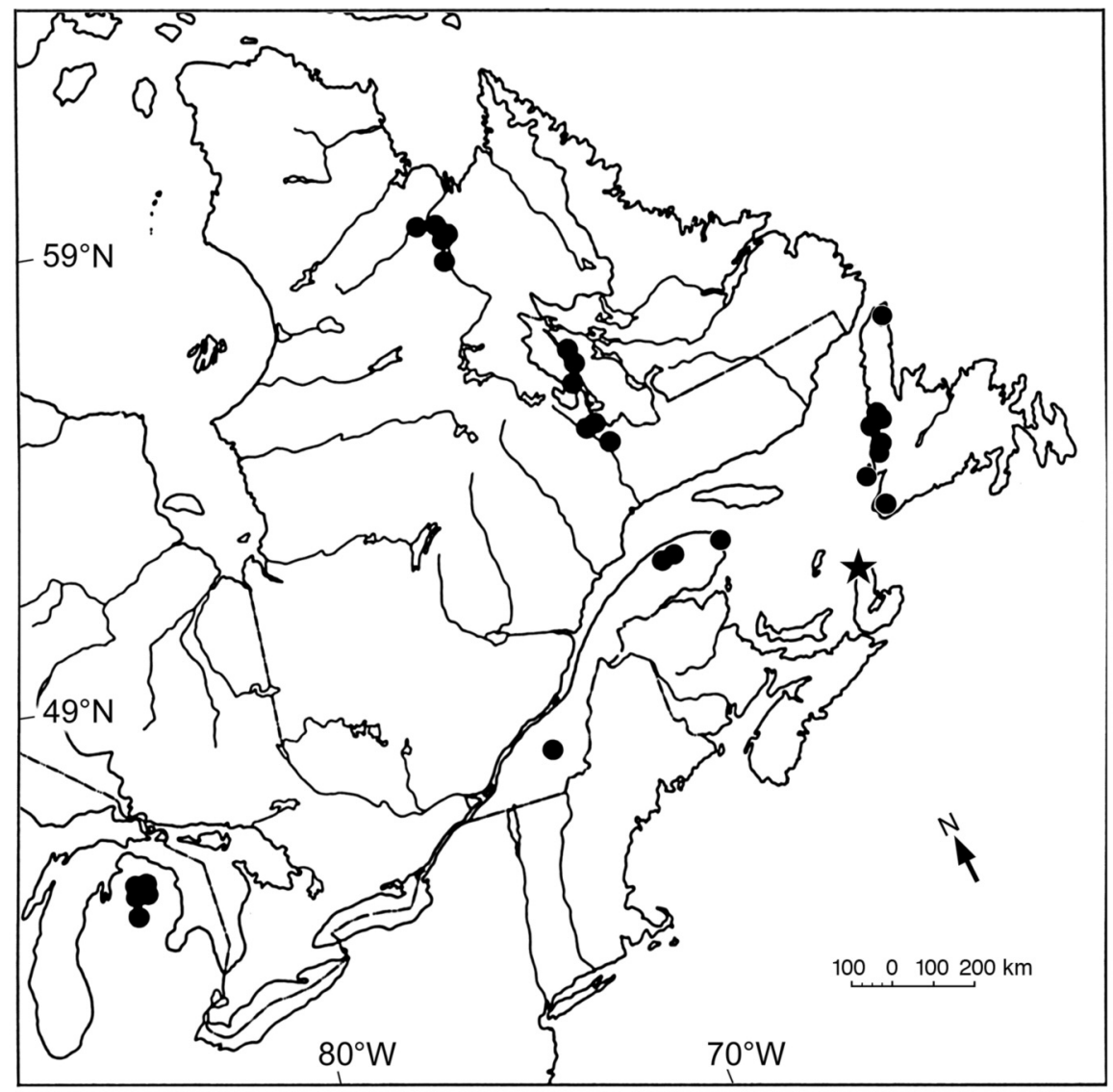

FIGURE 1. Distribution of Altai Fescue (Festuca altaica) in eastern North America, including the collection reported here from Nova Scotia (star). Sources: Aiken and Darbyshire (1990) and Atlantic Canada Conservation Data Centre, Sackville, New Brunswick, Canada.

(1982); common names of vascular plants are from Brouillet et al. (2010+). Provincial status ranks (Sranks) in Table 2 were developed using the methods of NatureServe (2017).

The widespread and isolated occurrences of $F$. altai$c a$ in eastern North America suggest that current metapopulations are relicts of a more continuous distribution when tundra vegetation followed the glacial margin retreat northward and was subsequently modified by long-term (Hypsithermal) and short-term Holocene climate variation (Roland and Smith 1969; Webb et al. 1983; Ritchie 1987; Viau et al. 2006; Capers et al. 2013). Species of plants (and animals) responded to these changes in complex ways, both as communities and individualistically (Overpeck et al. 1992; Henry and Molau 1997; Jump and Peñuelas 2005; Walther 2010). A somewhat similar distribution is seen for Timber Oatgrass (Danthonia intermedia Vasey; Cayouette and Darbyshire 1987; Darbyshire 2003). Although this latter species has not been found in Nova Scotia, both are relatively large-seeded grasses with boreal, arctic, or alpine affinities and no obvious means of long distance seed dispersal.

A combination of character states easily distinguished F. altaica from other species of Festuca in Nova Scotia in either vegetative or reproductive states. Measurements and observations of the limited material of $F$. altaica available from the Nova Scotia population showed character states well within the range reported for the species as a whole as listed below (Darbyshire and Pavlick 2007). It is a densely tufted grass with plentiful sterile shoots arising from within the persistent old leaf sheaths (intravaginal shoots) and, unlike Red Fescue (F. rubra L.) and Proliferous Fescue (F. prolifera (Piper) Fernald), creeping rhizomes are absent, although short extravaginal shoots may sometimes be present. Other species of Festuca present in Nova Scotia - Hair Fescue (F. filiformis Pourret), Nodding Fescue 

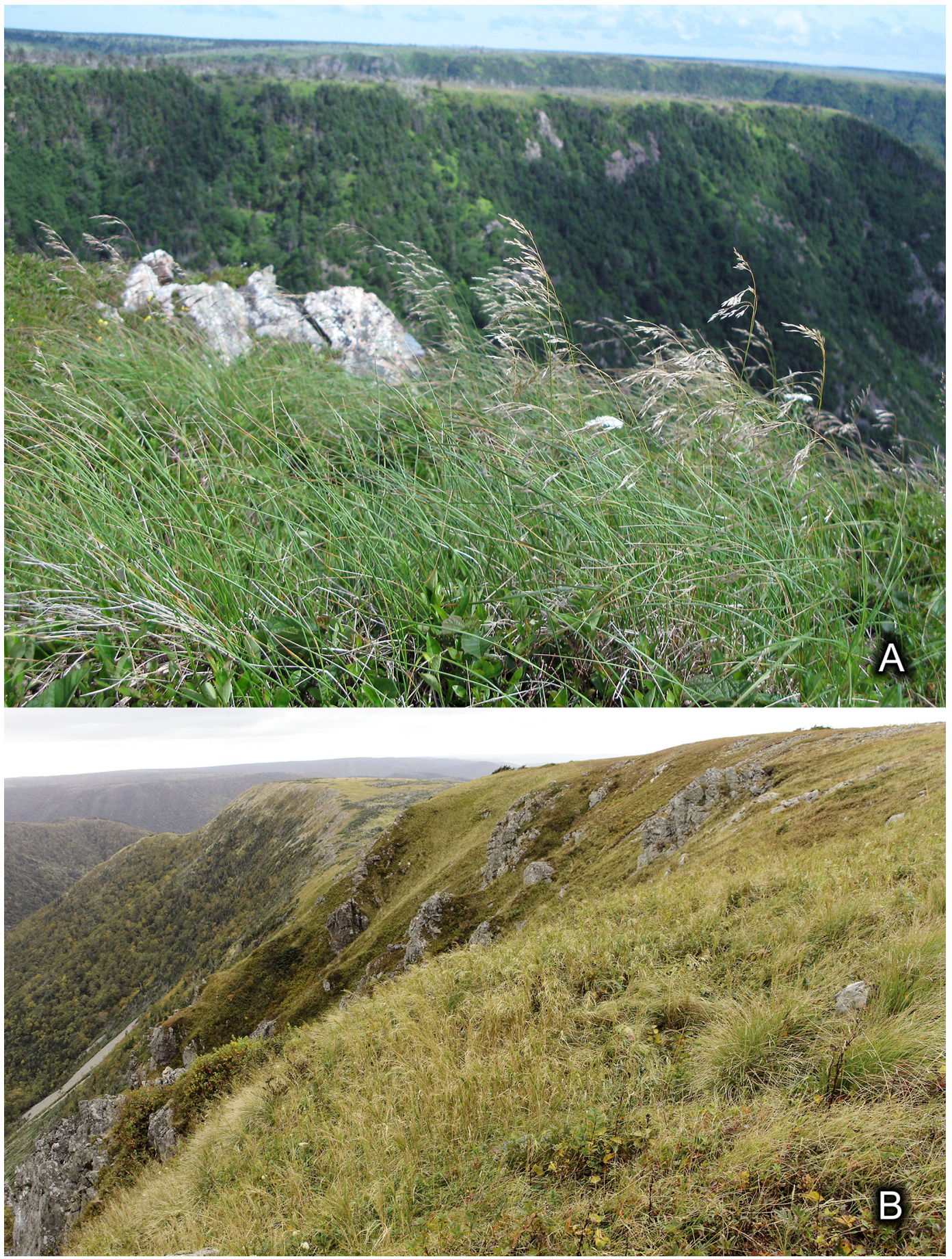

Figure 2. Alpine vegetation on Polletts Cove plateau, Nova Scotia, with Altai Fescue (Festuca altaica) in foreground. A. 15 July 2016. Photo: S. Blaney. B. 4 October 2013. Photo: S. Basquill. 
TABLE 1. Percentage cover of vegetation in two plots $\left(25 \mathrm{~m}^{2}\right)$ containing Altai Fescue (Festuca altaica) at Polletts Cove plateau, Nova Scotia. The total number of species (and unique species) at plot SB1066 at the crest of the slope and plot SB1216 on the upper slope were 22 (7) and 32 (17), respectively.

\begin{tabular}{|c|c|c|c|}
\hline \multirow{2}{*}{ Species } & & \multicolumn{2}{|c|}{ Cover, $\%$} \\
\hline & & Plot SB1066 & Plot SB1216 \\
\hline \multicolumn{4}{|l|}{ WOODY PLANTS } \\
\hline Green Alder & Alnus alnobetula subsp. crispa (Aiton) Raus & 1.50 & 3.00 \\
\hline Black Chokeberry & Aronia melanocarpa (Michaux) Elliot & 0.10 & 0.03 \\
\hline Beaked Hazel & Corylus cornuta Marshall & - $^{*}$ & 0.10 \\
\hline Northern Bush-honeysuckle & Diervilla lonicera Miller & - & 0.10 \\
\hline Mountain Holly & Ilex mucronata (L.) M. Powell, Savolainen \& S. Andrews & 0.50 & - \\
\hline White Spruce & Picea glauca (Moench) Voss (single tree $<0.5 \mathrm{~m}$ tall) & 0.50 & - \\
\hline Virginia Rose & Rosa virginiana Miller & 0.05 & 0.20 \\
\hline Broad-leaved Meadowsweet & Spiraea alba var. latifolia (Aiton) Dippel & 1.00 & 0.10 \\
\hline Lowbush Blueberry & Vaccinium angustifolium Aiton & 15.00 & - \\
\hline Northern Blueberry & Vaccinium boreale I. V. Hall \& Aalders & - & 1.00 \\
\hline \multicolumn{4}{|l|}{ HERBACEOUS PLANTS } \\
\hline Common Yarrow & Achillea millefolium $\mathrm{L}$. & 0.10 & 0.10 \\
\hline Rough Bentgrass & Agrostis scabra Willdenow & - & 0.10 \\
\hline Alpine Bistort & Bistorta vivipara (L.) Delarbre & - & $<0.01$ \\
\hline Canada Bluejoint & Calamagrostis canadensis (Michaux) Palisot de Beauvois & 15.00 & - \\
\hline Sedge species & Carex sp. & 0.02 & - \\
\hline Bluebead Lily & Clintonia borealis (Aiton) Rafinesque & 0.10 & 0.30 \\
\hline Goldthread & Coptis trifolia (L.) Salisbury & - & 0.10 \\
\hline Bunchberry & Cornus canadensis $\mathrm{L}$. & 0.01 & - \\
\hline Wavy Hairgrass & Deschampsia flexuosa (L.) Trinius & 5.00 & 1.00 \\
\hline Flat-topped White Aster & Doellingeria umbellata (Miller) Nees von Esenbeck & 0.50 & 4.00 \\
\hline Stiff Eyebright & Euphrasia stricta J. F. Lehmann & - & 0.10 \\
\hline Altai Fescue & Festuca altaica Trinius & 30.00 & 60.00 \\
\hline Wild Strawberry & Fragaria virginiana Duchesne & - & 0.02 \\
\hline Hairy Woodrush & Luzula acuminata Rafinesque & - & 0.10 \\
\hline Three-leaved Rattlesnakeroot & Nabalus trifoliolatus Cassini & 1.00 & 0.01 \\
\hline Whorled Wood Aster & Oclemena acuminata (Michaux) Greene & 0.50 & - \\
\hline Three-tooth Cinquefoil & Sibbaldia tridentata (Aiton) Paule \& Soják & 0.03 & 1.00 \\
\hline Downy Goldenrod & Solidago puberula Nuttall & 2.00 & 0.03 \\
\hline Mountain Cranberry & Vaccinium vitis-idaea $\mathrm{L}$. & 0.10 & 0.10 \\
\hline \multicolumn{4}{|l|}{ BRYOPHYTES AND LICHENS } \\
\hline Stubby Stalked Lichen & Cladonia caespiticia (Persoon) Flörke & - & 0.01 \\
\hline Forking Lichen & Cladonia furcata (Hudson) Schrader & - & 0.01 \\
\hline Pebbled Pixie-cup Lichen & Cladonia pyxidata (L.) Hoffmann & - & 0.01 \\
\hline Wavy-leaved Broom Moss & Dicranum polysetum Swartz & - & 0.01 \\
\hline Stairstep Moss & Hylocomium splendens (Hedwig) Schimper & - & 1.00 \\
\hline Pellucid Plait Moss & Hypnum imponens Hedwig & - & 0.10 \\
\hline Red-stemmed Feather Moss & Pleurozium schreberi (von Bridel) Mitten & 0.01 & 1.00 \\
\hline Yellow-green Rock Moss & Racomitrium heterostichum (Hedwig) von Bridel & - & 0.01 \\
\hline Wooly Rock Moss & Racomitrium lanuginosum (Hedwig) von Bridel & - & 0.01 \\
\hline
\end{tabular}

*Indicates absence or undetected.

(F. subverticillata (Persoon) E. B. Alexeev), and Hard Fescue (F. trachyphylla (Hackel) Krajina) — lack rhizomes entirely.

Leaf blade characters are useful for identifying Festuca species (Darbyshire and Pavlick 2007). The leaf blades of the sterile shoots of $F$. altaica are conduplicate or convolute (rarely flat), 2-4 mm wide, up to about $50 \mathrm{~cm}$ long, strongly scabrous on the abaxial surface, and short pubescent (sometimes sparsely) on the adaxial surface. In cross section, "girders" of sclerenchyma tissue are present at the major veins, extending from the abaxial to adaxial epidermis, while, at the minor veins, "pillars" of sclerenchyma tissue extend from the abaxial epidermis to the vein. In Nova Scotia, only F. subverticillata has sclerenchyma girders, but this species has flexuous leaf blades (3) 5-10 mm wide (see illustrations in Darbyshire and Pavlick 2007) and grows in lowland deciduous or mixed forests.

Lemmas of $F$. altaica are (6.5) 7.5-9.0 (12.0) mm long with a terminal awn to about $1.5 \mathrm{~mm}$ long, whereas the lemmas of $F$. filiformis and $F$. subverticillata are shorter ( $\leq 4.5 \mathrm{~mm}$ long) and lack awns. The lemmas of F. trachyphylla are $3.8-6.5 \mathrm{~mm}$ long and awned. Anthers of $F$. altaica are 2.6-4.5 (5) mm long, whereas the anthers of $F$. filiformis and $F$. subverticillata are $\leq 2.2 \mathrm{~mm}$ long and those of F. trachyphylla and F. rubra are 
TABLE 2. Additional significant species at the Polletts Cove site and the Blair River ravine, Nova Scotia.

\begin{tabular}{|c|c|c|c|}
\hline Species & & No & $\begin{array}{l}\text { Status in } \\
\text { Nova Scotia, } \\
\text { no. known } \\
\text { sites }^{\ddagger}\end{array}$ \\
\hline Cream-flowered Rockcress & Arabis pycnocarpa M. Hopkins & Widespread & S1S2, 7 \\
\hline Field Wormwood & Artemisia campestris L. & Boreal & $\mathrm{S} 1,2$ \\
\hline Bog Birch & Betula pumila L. var. pumila* & Boreal & $\mathrm{S} 2,11$ \\
\hline Alpine Bistort & Bistorta vivipara (L.) Delarbre* & Arctic/alpine & $\mathrm{S} 1,2$ \\
\hline Hair-like Sedge & Carex capillaris L. & Boreal, arctic/alpine & $\mathrm{S} 2,13$ \\
\hline Single-spike Sedge & Carex scirpoidea Michaux subsp. scirpoidea & Arctic/alpine & $\mathrm{S} 2,13$ \\
\hline Laurentian Bladder Fern & Cystopteris laurentiana (Weatherby) Blasdell & Eastern & $\mathrm{S} 2,10$ \\
\hline Rock Draba & Draba arabisans Michaux & Eastern & S2, 16 \\
\hline Meadow Barley & Hordeum brachyantherum Nevski & \multicolumn{2}{|l|}{$\begin{array}{l}\text { Western (also northwestern } \\
\text { Newfoundland and } \\
\text { southern Labrador) }\end{array}$} \\
\hline Spiked Woodrush & Luzula spicata (L.) de Candolle* & Boreal & $\mathrm{S} 1,4$ \\
\hline Highland Rush & $\begin{array}{l}\text { Oreojuncus trifidus (L.) Záveská, } \\
\text { Drábková \& Kirschner* }\end{array}$ & Eastern & $\mathrm{S} 2 \mathrm{~S} 3,18$ \\
\hline Saint John River Locoweed & Oxytropis campestris var. johannensis Fernald & Eastern & $\mathrm{S} 1 \mathrm{~S} 2,5$ \\
\hline Glaucous Bluegrass & Poa glauca Vahl* & Boreal & $\mathrm{S} 2 \mathrm{~S} 3,20$ \\
\hline Nodding Saxifrage & Saxifraga cernua $\mathrm{L}$. & Arctic/alpine & $\mathrm{S} 1,1$ \\
\hline Purple Mountain Saxifrage & Saxifraga oppositifolia L. & Arctic/alpine & $\mathrm{S} 1,2$ \\
\hline Laestadius' Saxifrage & $\begin{array}{l}\text { Saxifraga paniculata subsp. laestadii (Neuman) } \\
\text { T. Karlsson }\end{array}$ & Boreal, arctic/alpine & S2, 16 \\
\hline Multi-rayed Goldenrod & Solidago multiradiata Aiton & Boreal & $\mathrm{S} 2,10$ \\
\hline Quill Lichen & Cladonia amaurocraea (Flörke) Schaerer* & Boreal, arctic/alpine & $\mathrm{S} 1,1$ \\
\hline
\end{tabular}

${ }^{*}$ Species found in close proximity to Altai Fescue (Festuca altaica) on the plateau crest and upper slopes; others were found on cliff or riparian habitats in the adjacent ravine. All species except Nodding Saxifrage (Saxifraga cernua) were found during the same 2013 survey that detected $F$. altaica.

†Source: Atlantic Canada Conservation Data Centre, Sackville, New Brunswick, Canada. Accessed 1 June 2017. *Includes the ones reported here.

mostly 2-3.5 mm long, although the anthers of Rock Red Fescue (F. rubra subsp. pruinosa (Hackel) Piper) may be up to $6.5 \mathrm{~mm}$ long. The apex of the ovaries in $F$. altaica is usually sparsely pubescent, but densely pubescent in F. subverticillata and glabrous in other Festuca species present in Nova Scotia.

Voucher specimens

Canada, Nova Scotia, Inverness Co., $46.927^{\circ} \mathrm{N}$, $60.669^{\circ} \mathrm{W}$, alpine summit, plateau barren, 18 July 2013 , C.S. Blaney, D.M. Mazerolle, and S.P. Basquill 8330. (ACAD, DAO, NBM, NSPM).

\section{Acknowledgements}

We thank Eugene Quigley and David Mazerolle for assistance with fieldwork.

\section{Literature Cited}

Aiken, S. G., and S. J. Darbyshire. 1990. Fescue Grasses (Festuca L.: Poaceae) of Canada. Publication 1844/E. Agriculture and Agri-Food Canada, Ottawa, Ontario, Canada.

Alexeev, E. B. 1985. Festuca L. (Poaceae) in Alaska et Canada. Novosti Sistematiki Vysshikh Rastenii 22: 5-35. [In Russian].

Barr, S. M., R. A. Jamieson, and R. P. Raeside. 1992. Geological map of Northern Cape Breton Island. DP ME 13, Version 2, 2006. Digital version of Geological Survey of Canada map 1752A. Geological Survey of Canada, Ottawa,
Ontario, Canada. Accessed 7 June 2017. https://novascotia .ca/natr/meb/download/dp013.asp.

Brouillet, L., F. Coursol, S. J. Meades, M. Favreau, M. Anions, P. Bélisle, and P. Desmet. 2010+. VASCAN, the database of vascular plants of Canada. Université de Montréal Biodiversity Centre, Montréal, Quebec, Canada. Accessed 22 September 2016. http://data.canadensys.net /vascan.

Capers, R. S., K. D. Kimball, K. P. McFarland, M. T. Jones, A. H. Lloyd, J. S. Munroe, G. Fortin, C. Mattrick, J. Goren, D. D. Sperduto, and R. Paradis. 2013. Establishing alpine research priorities in northeastern North America. Northeastern Naturalist 20: 559-577. https://doi .org/10.1656/045.020.0406

Cayouette, J., and S. J. Darbyshire. 1987 [1988]. La répartition de Danthonia intermedia dans l'est du Canada. Le Naturaliste canadien 114: 217-220.

Darbyshire, S. J. 2003. Danthonia DC. Pages 301-306 in Flora of North America North of Mexico, Volume 25: Magnoliophyta: Commelinidae (in Part): Poaceae, Part 2. Edited by Flora of North America Editorial Committee. Oxford University Press, New York, New York, USA.

Darbyshire, S. J., and L. E. Pavlick. 2007. Festuca L. Pages 389-443 in Flora of North America North of Mexico, Volume 24: Magnoliophyta: Commelinidae (in Part): Poaceae, Part 1. Edited by Flora of North America Editorial Committee. Oxford University Press, New York, New York, USA.

Esslinger, T. L. 2015. A cumulative checklist for the lichenforming, lichenicolous and allied fungi of the continental 
United States and Canada. Version 20. North Dakota State University, Fargo, North Dakota, USA. Accessed 22 September 2016. http://www.ndsu.edu/pubweb/ esslinge/ch cklst/chcklst7.htm.

Harms, V. L. 1985. A reconsideration of the nomenclature and taxonomy of the Festuca altaica complex (Poaceae) in North America. Madroño 32: 1-10.

Henry, G. H. R., and U. Molau. 1997. Tundra plants and climate change: the International Tundra Experiment (ITEX). Global Change Biology 3 (Suppl. 1): 1-9. https://doi.org/ 10.1111/j.1365-2486.1997.gcb132.x

Ireland, R. R. 1982. Moss Flora of the Maritime Provinces. Publications in botany 13. National Museum of Natural Sciences, Ottawa, Ontario, Canada.

Jones, M. T., and L. L. Willey. 2012. Eastern Alpine Guide: Natural History and Conservation of Mountain Tundra East of the Rockies. Beyond Ktaadn, Inc. and Boghaunter Books, New Salem, Massachusetts, USA.

Jump, A. S., and J. Peñuelas. 2005. Running to stand still: adaptation and the response of plants to rapid climate change. Ecology Letters 8: 1010-1020. https://doi.org/10 $.1111 / \mathrm{j} .1461-0248.2005 .00796 . \mathrm{x}$

NatureServe. 2017. Conservation status assessment: identifying threatened species and ecosystems. NatureServe, Arlington, Virginia, USA. Accessed 9 June 2017. http:// www.natureserve.org/conservation-tools/conservationstatus-assessment.

Overpeck, J. T., R. S. Webb, and T. Webb, III. 1992. Mapping eastern North American vegetation change of the past $18 \mathrm{ka}$ : no-analogs and the future. Geology 20: 1071-1074. https://doi.org/10.1130/0091-7613(1992)020<1071:MEN $\mathrm{AVC}>2.3 . \mathrm{CO} ; 2$

Pavlick, L. E., and J. Looman. 1984. Taxonomy and nomenclature of rough fescues, Festuca altaica, F. campestris ( $F$. scabrella var. major), and F. hallii, in Canada and the adjacent part of United States. Canadian Journal of Botany 62: 1739-1749. https://doi.org/10.1139/b84-235

Ritchie, J. C. 1987. Postglacial Vegetation of Canada. Cambridge University Press, Cambridge, United Kingdom. https://doi.org/10.1002/jqs.3390050209

Roland, A. E. 1982. Geological Background and Physiography of Nova Scotia. Nova Scotia Institute of Science, Halifax, Nova Scotia, Canada.

Roland, A. E., and E. C. Smith. 1969. The flora of Nova Scotia. Part II. The dicotyledons. Proceedings of the Nova Scotia Institute of Science 26: 277-742.

Saarela, J. M., P. C. Sokoloff, and R. D. Bull. 2017. Vascular plant biodiversity of the lower Coppermine River valley and vicinity (Nunavut, Canada): an annotated checklist of an Arctic flora. PeerJ 5: e2835. https://doi.org/10.7717/peerj .2835

Tsvelev, N. N. 1983. Grasses of the Soviet Union. Oxonion Press, New Delhi, India.

Viau, A. E., K. Gajewski, M. C. Sawada, and P. Fines. 2006. Millennial-scale temperature variations in North America during the Holocene. Journal of Geophysical Research 111: D09102. https://doi.org/10.1029/2005JD006031

Walther, G.-R. 2010. Community and ecosystem responses to recent climate change. Philosophical Transactions of the Royal Society B 365: 2019-2024. https://doi.org/10.1098 /rstb.2010.0021

Webb, T., III, P. J. H. Richard, and R. J. Mott. 1983. A mapped history of Holocene vegetation in southern Quebec. Syllogeus 49: 273-331.

Received 23 September 2016

Accepted 9 August 2017 